\title{
Bombesin Receptors in Distinct Tissue Compartments of Human Pancreatic Diseases
}

\author{
Achim Fleischmann, Ursula Läderach, Helmut Friess, Markus W. Buechler, and \\ Jean Claude Reubi
}

Division of Cell Biology and Experimental Cancer Research (AF, UL, JCR), Institute of Pathology, University of Berne, and Department of Visceral and Transplantation Surgery (HF, MWB), Inselspital, University of Berne, Berne, Switzerland

\begin{abstract}
SUMMARY: Overexpression of receptors for regulatory peptides in various human diseases is reportedly of clinical interest. Among these peptides, bombesin and gastrin-releasing peptide (GRP) have been shown to play a physiological and pathophysiological role in pancreatic tissues. Our aim has been to localize bombesin receptors in the human diseased pancreas to identify potential clinical applications of bombesin analogs in this tissue. The presence of bombesin receptor subtypes has been evaluated in specimens of human pancreatic tissues with chronic pancreatitis $(n=23)$ and ductal pancreatic carcinoma ( $\mathrm{n}$ $=29$ ) with in vitro receptor autoradiography on tissue sections incubated with ${ }^{125} \mathrm{I}-\left[\mathrm{Tyr}^{4}\right]$-bombesin or the universal ligand ${ }^{125} \mathrm{I}-\left[\mathrm{D}-\mathrm{Tyr}^{6}, \beta-\mathrm{Ala}^{11}, \mathrm{Phe}^{13}, \mathrm{Nle}^{14}\right]$-bombesin(6-14) as radioligands and displaced by subtype-selective bombesin receptor agonists and antagonists. GRP receptors were identified in the pancreatic exocrine parenchyma in 17 of 20 cases with chronic pancreatitis. No measurable bombesin receptors were found in the tumor tissue of ductal pancreatic carcinomas, however, GRP receptors were detected in a subset of peritumoral small veins in 19 of 29 samples. Moreover, residual pancreatic islets in these tissues were shown to express the BB3 receptor subtype. These data demonstrate the presence of bombesin receptors in three distinct tissue compartments of the pancreas, namely GRP receptors in the exocrine parenchyma in chronic pancreatitis and in peritumoral vessels around ductal pancreatic carcinomas, and BB3 receptors in residual pancreatic islets. Such a selective expression of bombesin receptor subtypes in pancreatic tissues may not only be of pathophysiological significance but may represent the basis for potential diagnostic and therapeutic clinical applications of bombesin analogs, including GRP receptor scintigraphy to differentiate chronic pancreatitis from ductal pancreatic carcinoma. (Lab Invest 2000, 80:1807-1817).
\end{abstract}

$N$ europeptide receptors are overexpressed in different human neoplastic and non-neoplastic diseases: somatostatin receptors in most neuroendocrine tumors (Reubi, 1995b), vasoactive intestinal peptide receptors in most epithelial tumors (Reubi, 1995a), gastrin-releasing-peptide (GRP) receptors in all prostatic carcinomas (Markwalder and Reubi, 1999), and a majority of breast cancers (Gugger and Reubi, 1999). Substance $P$ receptors can be up-regulated in inflammatory bowel diseases (Mantyh et al, 1991) and rheumatoid arthritis (Walsh et al, 1992). In addition, they can be overexpressed in peritumoral vessels of various tumor types (Hennig et al, 1995), an observation made with somatostatin receptors as well (Denzler and Reubi, 1999). These in vitro results have already led to the development of diagnostic and radiotherapeutic applications, using radiolabeled peptides for in vivo receptor scintigraphy (Behr et al, 1999; Krenning et al, 1995; Virgolini et al, 1994) or peptide radiotherapy (Otte et al, 1998).

Received June 23, 2000.

Address reprint requests to: Dr. Jean Claude Reubi, Division of Cell Biology and Experimental Cancer Research, Institute of Pathology, University of Berne, Murtenstrasse 31, P.O. Box 62, CH-3010 Berne, Switzerland. Fax: 4131632 8999; E-mail: reubi@patho.unibe.ch
The family of bombesin-like peptides, including the amphibian peptide bombesin as well as the mammalian counterparts GRP and neuromedin B (Erspamer, 1988), is involved in the regulation of a large number of biological processes in the gut such as exocrine secretion, smooth muscle contraction, and gastrointestinal hormone release. It is of particular interest that these peptides also function as growth factors in several normal and neoplastic tissues, including normal rat pancreas (Lehy and Puccio, 1988), human small-cell lung cancer, gastrinomas, and in breast, gastric, colorectal, and pancreatic cancer cell lines (Chung et al, 1992; Cuttitta et al, 1985; Frucht et al, 1992; Wang et al, 1996; Yano et al, 1992). These peptides were shown to participate in autocrine tumor growth stimulation (Cuttitta et al, 1985). Bombesin-like peptides mediate their action through membranebound receptors (Kroog et al, 1995). There have been four different bombesin receptor subtypes described: GRP receptors (with high affinity for GRP) (Spindel et al, 1990), neuromedin B receptors (with high affinity for neuromedin B) (Von Schrenck et al, 1989), BB3 receptors (with high affinity for [D-Trp ${ }^{6}, \beta-\mathrm{Ala}^{11}, \mathrm{Phe}^{13}$, $\mathrm{Nle}^{14}$ ]-bombesin(6-14)) (Fathi et al, 1993; Pradhan et al, 1998), and BB4 receptors (Nagalla et al, 1995). These receptors belong to the large superfamily of G-protein coupled receptors with seven transmembrane domains. 
In mammals, the endogenous GRP ligand has been shown, under normal conditions, to be located primarily in nerves of both the peripheral autonomic and central nervous systems (Dockray et al, 1979; Moghimzadeh et al, 1983). In the human pancreas, bombesin-like immunoreactivity has been localized by immunohistochemistry to nerve fibers innervating pancreatic acini, capillaries, ducts, and islets (Shimosegawa et al, 1993). Bombesin receptors have been identified with binding techniques under various experimental conditions in rat, guinea pig, and human pancreas tissues (Hajri et al, 1996; Huang et al, 1990; Jensen et al, 1978; Tang et al, 1997) indicative of a possible functional role of bombesin-like peptides in this organ (Deschodt-Lanckman et al, 1976). Information on the exact localization and distribution of bombesin receptors and their subtypes in the diseased human pancreas is, however, very limited. The purpose of the present study was to evaluate the localization and distribution of bombesin receptor subtypes in human tissue sections of chronic pancreatitis and pancreatic ductal carcinomas with in vitro receptor autoradiography, using the GRP receptor preferring ligand ${ }^{125} \mathrm{I}-\mathrm{Tyr}^{4}$-bombesin or a universal ligand recognizing all four bombesin receptor subtypes, ${ }^{125}$ I-
$\left[\mathrm{D}-\mathrm{Tyr}^{6}, \quad \beta\right.$-Ala $\left.{ }^{11}, \quad \mathrm{Phe}^{13}, \quad \mathrm{Nle}^{14}\right]$-bombesin(6-14) (Pradhan et al, 1998).

\section{Results}

The primary finding of this study is the expression of bombesin receptor subtypes in the following pancreatic tissues: (a) GRP receptors in the exocrine parenchyma of chronically inflamed pancreas; (b) GRP receptors in the wall of small blood vessels located in the immediate surroundings of ductal pancreatic carcinomas; and (c) BB3 receptors in residual pancreatic islets found in these pancreatic samples.

Table 1 summarizes the bombesin receptor data for 23 tissue samples with chronic pancreatitis. Twenty samples contained residual pancreatic parenchyma, three consisted primarily of fibrosis with less than $95 \%$ of parenchyma. Seventeen of the twenty parenchymatous samples (85\%) expressed bombesin receptors in the residual exocrine parenchyma. Ten of the receptor-positive specimens showed a homogenous distribution of the receptors over the whole exocrine parenchyma, whereas the remaining seven receptorpositive samples showed a more focal distribution of the receptors in the parenchyma. Evidence for the

Table 1. Bombesin-Receptor Expression in Chronic Pancreatitis ${ }^{\dagger}$

\begin{tabular}{|c|c|c|c|c|c|}
\hline \multirow[b]{2}{*}{ No. } & \multicolumn{3}{|c|}{ Chronic pancreatitis } & \multicolumn{2}{|c|}{$\begin{array}{c}\text { Bombesin-Receptor } \\
\text { expression (GRP-R subtype) }\end{array}$} \\
\hline & Patient code & $\begin{array}{l}\text { Grade of } \\
\text { fibrosis }\end{array}$ & $\begin{array}{c}\text { Grade of } \\
\text { chronic } \\
\text { inflammation }\end{array}$ & $\begin{array}{c}\text { Exocrine } \\
\text { parenchyma }\end{array}$ & Veins \\
\hline 1 & BP 1344 & $70 \%$ & moderate & + & - \\
\hline 2 & BP 1315 & $30 \%$ & low-moderate & focal + & - \\
\hline 3 & BP 1286 & $60 \%$ & low & + & - \\
\hline 4 & BP 1268 & $80 \%$ & moderate & focal + & - \\
\hline 5 & BP 1231 & $15 \%$ & low & focal + & - \\
\hline 6 & BP 1 & $40 \%$ & low & + & - \\
\hline 7 & BP 1051 & $60 \%$ & moderate & focal + & - \\
\hline 8 & BP 824 & $70 \%$ & moderate & + & - \\
\hline 9 & LOC & $20 \%$ & low & + & - \\
\hline 10 & GAL & $80 \%$ & low & + & - \\
\hline 11 & ROS & $5 \%$ & moderate-high & + & - \\
\hline 12 & SUP & $>95 \%$ & moderate & neg & - \\
\hline 13 & DEN & $50 \%$ & low & focal + & - \\
\hline 14 & FRE & $20 \%$ & low & + & - \\
\hline 15 & HUB & $5 \%$ & low & - & - \\
\hline 16 & BAL & $30 \%$ & moderate & focal + & - \\
\hline 17 & $\mathrm{BUH}$ & $15 \%$ & high* & - & - \\
\hline 18 & KLO & $>95 \%$ & low-moderate & neg & - \\
\hline 19 & $\mathrm{KOC}$ & $80 \%$ & low-moderate* & + & - \\
\hline 20 & WEN & $>95 \%$ & high* & neg & - \\
\hline 21 & HAN & $50 \%$ & high & focal + & - \\
\hline 22 & BEG & $70 \%$ & moderate & + & - \\
\hline 23 & KNE & $30 \%$ & low & - & - \\
\hline \multicolumn{6}{|c|}{$\begin{array}{l}\text { † } 23 \text { patients. } \\
+, \text { Bombesin receptors present, characterized as GRP-R subtype. } \\
-, \text { No Bombesin receptors. } \\
\text { neg, not sufficient parenchyma in the sections. } \\
\text { × signs of acute inflammation as well. }\end{array}$} \\
\hline
\end{tabular}


expression of the GRP receptor subtype of bombesin receptors in the exocrine parenchyma is threefold: (a) in all cases the tissue was strongly labeled with the GRP receptor-preferring radioligand ${ }^{125} \mathrm{I}-\left[\mathrm{Tyr}^{4}\right]$ bombesin; (b) in competition experiments using ${ }^{125} \mathrm{I}-\left[\mathrm{Tyr}^{4}\right]$ bombesin, a high affinity binding for GRP and bombesin and a lower affinity for neuromedin B were observed; (c) in all cases the parenchyma could also be labeled with the universal ligand ${ }^{125} \mathrm{I}-\left[\mathrm{D}-\mathrm{Ty} \mathrm{r}^{6}\right.$, $\beta$-Ala ${ }^{11}, \mathrm{Phe}^{13}, \mathrm{Nle}^{14}$ ]-bombesin(6-14) (this ligand was displaced by nanomolar concentrations of GRP and bombesin but not neuromedin B); and (d) two potent GRP receptor antagonists, [D-Phe ${ }^{6}$-bombesin(6-13) NHEt and [D-Phe ${ }^{6}$, Leu $^{13} \psi\left(\mathrm{CH}_{2} \mathrm{NH}\right)$ Leu $\left.^{14}\right]-$ bombesin(6-14) (Coy et al, 1989; Jensen and Coy,
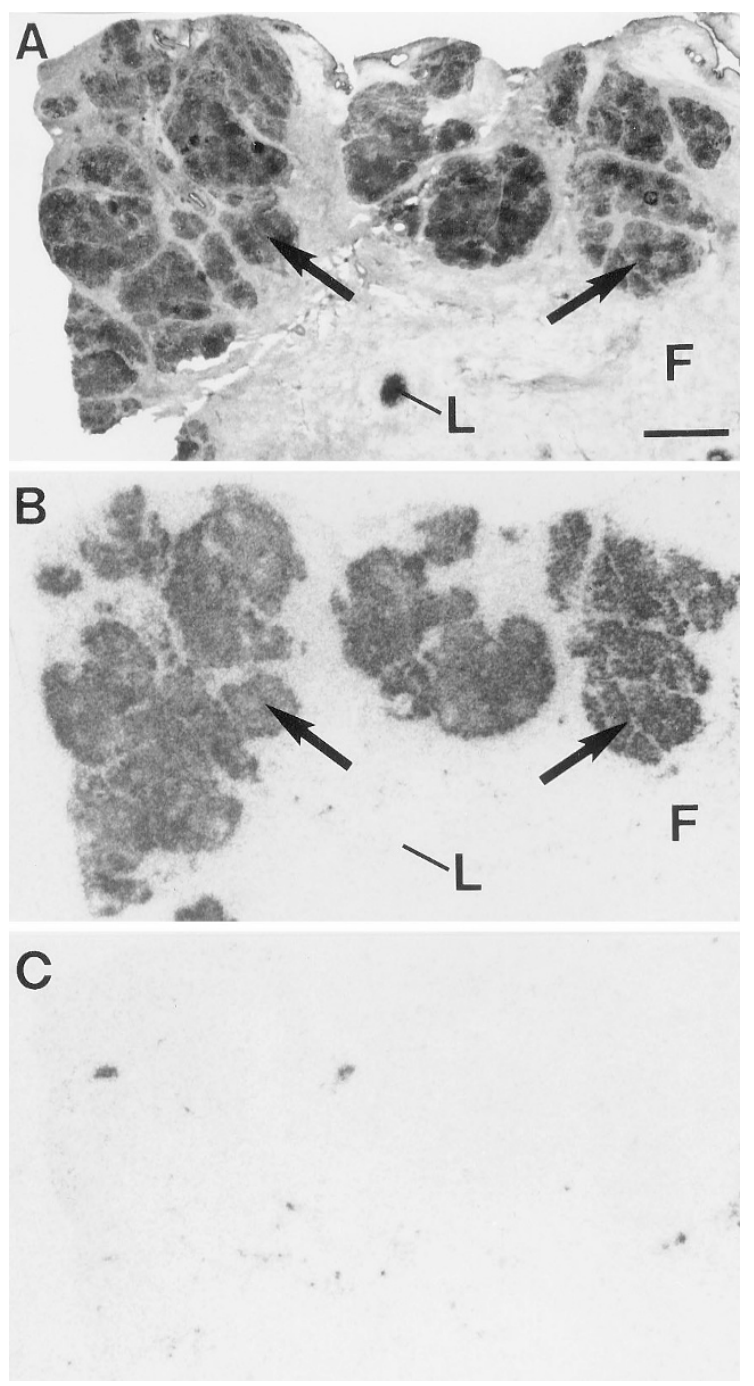

\section{Figure 1.}

Identification of a homogenous dense distribution of GRP receptors in the exocrine parenchyma in chronic pancreatitis. $A$, Hematoxylin and eosin (H\&E) stained section shows an example of chronic pancreatitis with residual pancreatic parenchyma (arrows) surrounded by fibrosis $(F$ and a lymphatic follicle $(L)$. Bar $=1 \mathrm{~mm}$. B, Autoradiogram showing total binding of ${ }^{125} \mathrm{I}-\left[\mathrm{Tyr}^{4}\right]$-bombesin. Strong and selective labeling of pancreatic parenchyma is seen (arrows). Neither the lymphatic follicle $(L)$ or the fibrotic areas $(F)$ have receptors. C, Autoradiogram showing nonspecific binding of ${ }^{125} \mathrm{I}-\left[\mathrm{Tyr}^{4}\right]-$ bombesin (in the presence of $10^{-6} \mathrm{M}$ GRP).
1991) were able, in nanomolar concentrations, to completely inhibit binding of either radioligand. Figure 1 shows one representative example of GRP receptorpositive exocrine parenchyma in chronic pancreatitis with a homogenous, high GRP receptor density. Figure 2 is an example of a focal expression of GRP receptors in the exocrine pancreatic parenchyma of a patient with chronic pancreatitis. Here, the receptors are predominantly expressed at the border of the pancreatic lobules. In three patients, the investigated parenchyma did not show any expression of GRP receptors. One of the patients had only discrete fibrosis and inflammation of the pancreatic tissue, reflect-
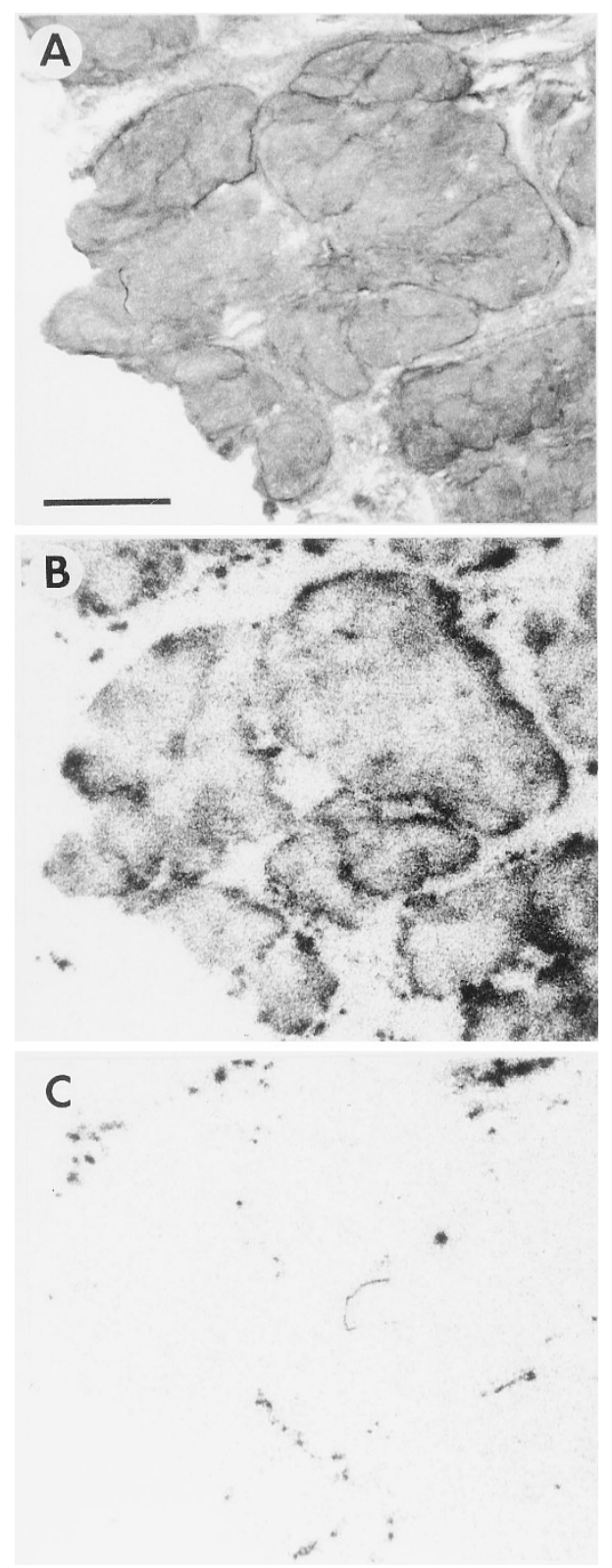

Figure 2.

Preferential focal distribution of GRP receptors at the border of exocrine parenchyma lobules in a case of chronic pancreatitis. $A$, H\&E stained section. Bar $=1 \mathrm{~mm}$. B, Autoradiogram showing total binding of ${ }^{125} \mid-\left[\right.$ Tyr $\left.r^{4}\right]$-bombesin. Marked labeling is seen at the border of the lobules. C, Autoradiogram showing nonspecific biding of ${ }^{125}$ - $\left[\mathrm{Tyr}^{4}\right]$-bombesin (in the presence of $10^{-6} \mathrm{M}$ GRP). 
ing a very mild form of chronic pancreatitis. In general, no correlation was observed between the expression of GRP receptors in the pancreatic parenchyma and the degree of adjacent fibrosis or assessed grade of inflammation in the investigated material (Table 1). No GRP receptor-positive blood vessels were detected in the specimens with chronic pancreatitis. Figure 3 is a representative example of a competition experiment showing the binding of ${ }^{125} \mathrm{I}-\left[\mathrm{Tyr}^{4}\right]$-bombesin to the exocrine parenchyma in chronic pancreatitis and its displacement by nanomolar concentrations of GRP and bombesin, but not neuromedin B or somatostatin. Figure 4, A to I, illustrates the binding of ${ }^{125} \mathrm{I}-\left[\mathrm{D}-\mathrm{Ty} \mathrm{r}^{6}\right.$, $\beta$-Ala $\left.{ }^{11}, \mathrm{Phe}^{13}, \mathrm{Nle}^{14}\right]$-bombesin(6-14) to the exocrine parenchyma in chronic pancreatitis with displacement by $50 \mathrm{~nm}\left[\mathrm{D}-\mathrm{Tyr}^{6}, \beta-\mathrm{Ala}^{11}\right.$, $\left.\mathrm{Phe}^{13}, \mathrm{Nle}^{14}\right]$-bombesin(614), GRP, and bombesin, but not by neuromedin $B$. Table 2 (left side) summarizes the $I_{50}$ values of
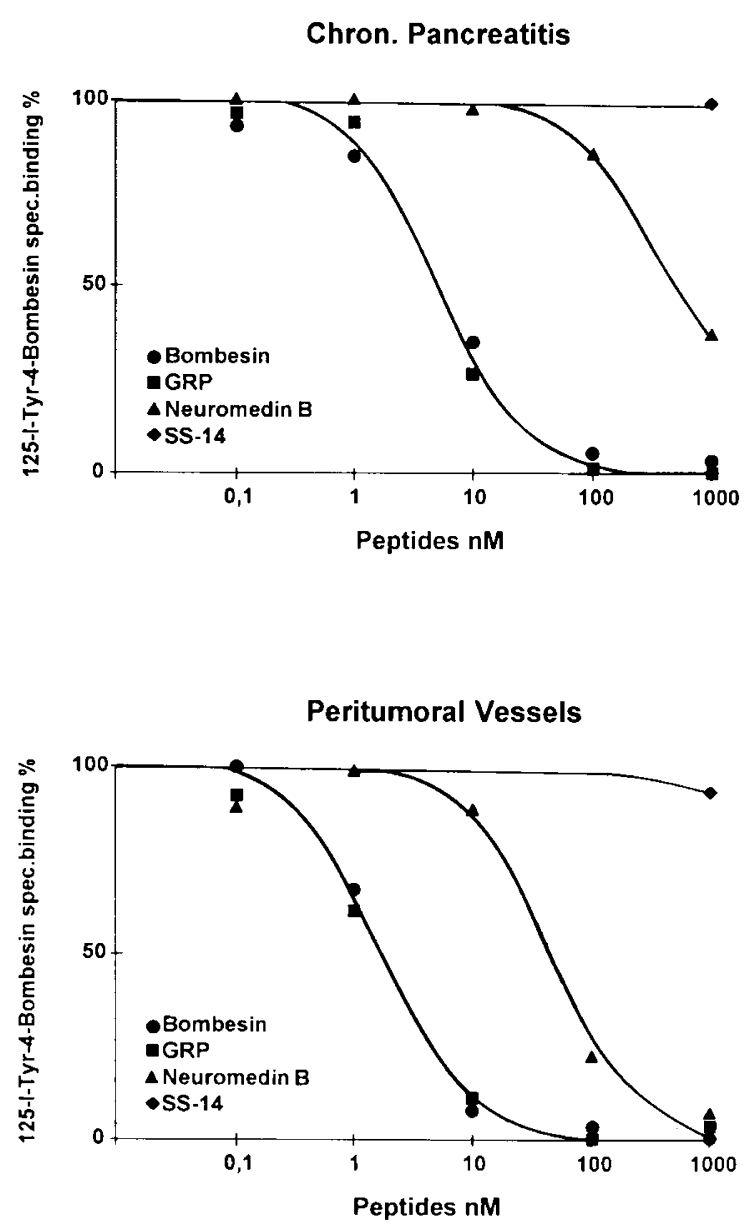

Figure 3.

High affinity and specificity of the ${ }^{125} \mathrm{I}-\left[\mathrm{Tyr}^{4}\right]$-bombesin binding in a displacement experiment. Sections containing GRP receptor-positive parenchyma in chronic pancreatitis samples or peritumoral vessels in pancreatic adenocarcinoma samples were incubated with ${ }^{125} \mathrm{I}-\left[\mathrm{Tyr} \mathrm{r}^{4}\right]$-bombesin and increasing concentrations of unlabeled bombesin $(\boldsymbol{\bullet})$, GRP $(\mathbf{\square})$, neuromedin $B(\mathbf{\Delta})$, and somatostatin-14 (४). Optical density was measured in parenchyma and vessels respectively, using a computer-assisted image processing system. High affinity displacement of the tracer is found with bombesin and GRP whereas neuromedin B shows lower affinity. Somatostatin 14 has no effect. Nonspecific binding was subtracted from all values. The observed rank order of potencies of analogs corresponds to the GRP receptor.
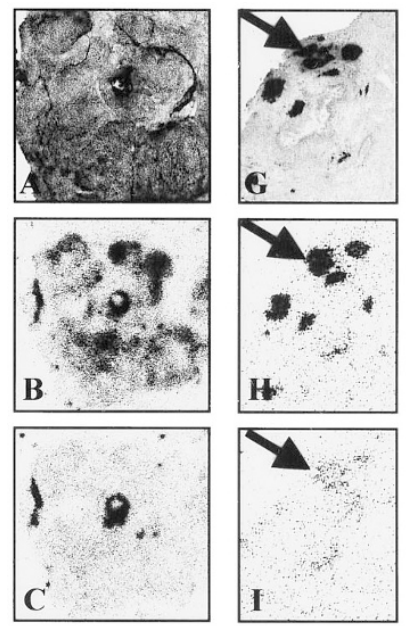

\section{+ univ. BN}
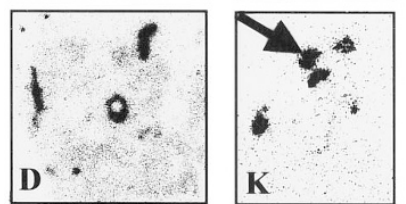

$$
+\mathbf{B N}
$$
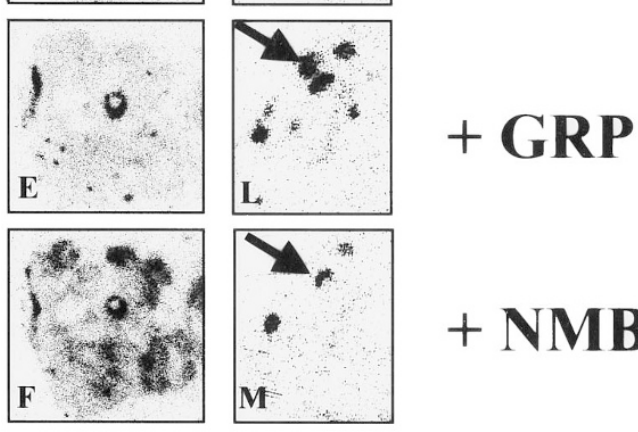

\section{$+\mathbf{N M B}$}

\section{Figure 4.}

Bombesin receptor subtypes in the exocrine parenchyma of chronic pancreatitis ( $A$ to $F$, GRP receptors) and in the residual pancreatic islets of a pancreatic carcinoma sample ( $G$ to $M$, BB3-receptors) using ${ }^{125} /$-[D-Tyr ${ }^{6}$, $\beta$-Ala ${ }^{11}, \mathrm{Phe}^{13}, \mathrm{Nle}^{14} \mathrm{~J}$-bombesin(6-14) as radioligand with selective competitors. $A$ and $G$, Stained sections: H\&E stain in $A$; synaptophysin immunostain in $G$, showing pancreatic islets (arrow). $B$ and $H$, Autoradiograms showing total binding of ${ }^{125} \mathrm{l}-\left[\mathrm{D}-\mathrm{Tyr}^{6}, \beta-\mathrm{Ala}^{11}\right.$, $\left.\mathrm{Phe}^{13}{ }^{13} \mathrm{Nle}^{14}\right]$-bombesin(6-14). Parenchyma $(B)$ and islets $(H)$ are strongly labeled. $C$ and $I$, Autoradiograms showing nonspecific binding of ${ }^{125}$-[D-Tyr ${ }^{6}, \beta$-Ala ${ }^{11}, \mathrm{Phe}^{13}$, Nle $\left.{ }^{14}\right]$-bombesin(6-14) (in presence of $50 \mathrm{~nm}\left[\mathrm{D}-\mathrm{Tyr}^{6}, \beta\right.$-Ala $\left.{ }^{11}, \mathrm{Phe}^{13}, \mathrm{Nle}^{14}\right]$-bombesin(6$14)=$ universal bombesin [univ. BN]). $D$ and $K$, Autoradiograms showing ${ }^{125}$ - $\left[\mathrm{D}-\mathrm{Tyr}^{6}, \beta-\mathrm{Ala}^{11}, \mathrm{Phe}^{13}, \mathrm{Nle}^{14}\right]$-bombesin(6-14) binding in presence of $50 \mathrm{~nm}$ of bombesin (BN); the ligand is displaced in the parenchyma $(D)$ but not in islets $(K)$. $E$ and $L$, Autoradiograms showing ${ }^{125}$ - $\left[\mathrm{D}-\mathrm{Tyr}^{6}, \beta-\mathrm{Ala}^{11}, \mathrm{Phe}^{13}\right.$ $\mathrm{Nle}^{14}$ ]-bombesin(6-14) binding in presence of $50 \mathrm{nM}$ of GRP. The ligand is displaced in $E$ but not in $L$. $F$ and $M$, Autoradiograms showing ${ }^{125} \mathrm{I}-\left[\mathrm{D}-\mathrm{Tyr}^{6}\right.$, $\beta$-Ala ${ }^{11}, \mathrm{Phe}^{13}, \mathrm{Nle}^{14} \mathrm{~J}$-bombesin(6-14) binding in presence of 50 nм neuromedin $B$. The ligand is neither displaced in $F$ nor in $M$.

various bombesin-related agonists and antagonists in displacing ${ }^{125} \mathrm{I}-\left[\mathrm{D}-\mathrm{Tyr}^{6}, \beta-\mathrm{Ala}^{11}, \mathrm{Phe}^{13}, \mathrm{Nle}^{14}\right.$ ]-bombesin(6-14) binding to the exocrine parenchyma of chronic pancreatitis.

Table 3 summarizes the bombesin receptor evaluation in 29 specimens of adenocarcinoma of the pancreas. None of the adenocarcinomas had a measurable level of receptors either with ${ }^{125} \mathrm{I}-\left[\mathrm{Tyr}^{4}\right]$-bombesin or with ${ }^{125} \mathrm{I}-\left[\mathrm{D}-\mathrm{Tyr}^{6}, \beta\right.$-Ala $\left.{ }^{11}, \mathrm{Phe}^{13}, \mathrm{Nle}^{14}\right]$-bombesin(6-14). An example of such a bombesin receptornegative tumor is shown in Figure 5. Four of eight 
Table 2. Affinity of Various Bombesin Analogs for Bombesin Receptors in Exocrine Pancreatic Parenchyma (Chronic Pancreatitis) or Pancreatic Islets Labeled with ${ }^{125}$-[D-Tyr ${ }^{6}, \beta$-Ala $\left.{ }^{11}, \mathrm{Phe}^{13}, \mathrm{Nle}^{14}\right]$-bombesin(6-14)

\begin{tabular}{lcc}
\hline \multicolumn{1}{c}{ Bombesin analogs } & $\begin{array}{c}\text { Exocrine parenchyma } \\
(\text { GRP-R })\end{array}$ & $\begin{array}{c}\text { Pancreatic islets } \\
\text { (BB3-R) }\end{array}$ \\
\hline [D-Tyr $^{6}, \beta-$-Ala $^{11}$, Phe $\left.^{13}, \mathrm{Nle}^{14}\right]$-bombesin(6-14) & $8 \pm 0.5$ & $2.4 \pm 0.9$ \\
Bombesin & $44 \pm 27$ & $>1000$ \\
GRP & $22 \pm 7.5$ & $>1000$ \\
NMB & $>1000$ & $>1000$ \\
SS-14 & $>1000$ & $>10,000$ \\
GRP antagonist ([D-Phe ${ }^{6}$-bombesin(6-13) NHEt) & $6.5 \pm 0.4$ & $>1000$ \\
\hline
\end{tabular}

$\mathrm{IC}_{50}$ in $\mathrm{nM}$; mean $\pm \mathrm{SEM}$ of at least three experiments.

tumor samples containing residual exocrine nonneoplastic pancreatic tissue in the resected material showed a weak and focally distributed expression of GRP receptors in the exocrine parenchyma. This tissue displayed histopathological changes consistent with chronic pancreatitis. Interestingly, in 19 of 29 tumor samples, a subset of peritumoral blood vessels also displayed GRP receptors; the labeled vessels were always small veins. A great variability of the GRP receptor incidence in the peritumoral veins was observed among the different samples, ranging from almost no receptors in some vessels to a high density of receptors in others. In several cases, a patchy, nonhomogeneous distribution of the GRP receptors was noticed within individual vessels. These results are also summarized in Table 3. The evidence for the expression of the GRP receptor subtype in the residual exocrine pancreatic parenchyma and in peritumoral vessels of the cancer samples is the same as mentioned above for the chronic pancreatitis samples: (a) labeling with ${ }^{125} \mathrm{I}-\left[\mathrm{Tyr}^{4}\right]$-bombesin; (b) high affinity displacement by GRP and bombesin; (c) labeling with ${ }^{125} \mathrm{I}-\left[\mathrm{D}-\mathrm{Tyr}^{6}, \beta-\mathrm{Ala}^{11}, \mathrm{Phe}^{13}, \mathrm{Nle}^{14}\right.$-bombesin(6-14); and (d) high affinity displacement by GRP, bombesin, and two selective GRP receptor antagonists. Two examples of GRP receptor-positive peritumoral veins are shown in Figure 6. The first example shows several GRP receptor-positive veins localized around a ductal pancreatic carcinoma. The other example is a high magnification of one peritumoral vein surrounding a ductal pancreatic carcinoma with mucinous components. The GRP receptor positivity in this vein is observed in the smooth muscle. Conversely, vascular GRP receptors could not be identified in the specimens with chronic pancreatitis. Figure 3 shows a representative example of a competition experiment showing binding of ${ }^{125} \mathrm{I}-\left[\mathrm{Tyr}^{4}\right]$-bombesin in a peritumoral vessel and its displacement by nanomolar concentrations of GRP and bombesin, but not neuromedin B or somatostatin.

In 15 of the samples with either chronic pancreatitis or ductal pancreatic cancers, areas containing residual pancreatic islets were identified. Whereas none of these islets could be identified with the GRP receptorpreferring ligand ${ }^{125} \mathrm{I}-\left[\mathrm{Tyr}^{4}\right]$-bombesin, they could, however, be strongly labeled with the universal ligand ${ }^{125} \mathrm{I}-\left[\mathrm{D}-\mathrm{Tyr}^{6}, \beta\right.$-Ala $\left.{ }^{11}, \mathrm{Phe}^{13}, \mathrm{Nle}^{14}\right]$-bombesin(6-14) as shown in Figure 4, G to $M$. In competition experi- ments, this radioligand could be selectively displaced by nanomolar concentrations of [D-Tyr ${ }^{6}, \beta$-Ala ${ }^{11}$, $\mathrm{Phe}^{13}, \mathrm{Nle}^{14}$-bombesin(6-14), although it was not displaced by GRP, bombesin, neuromedin B, or by GRP receptor antagonists (Fig. 4B and Table 2). These pharmacological characteristics strongly suggest the presence of BB3 receptors in the human pancreatic islets (Pradhan et al, 1998).

We have attempted to identify bombesin receptors with the same methodology in the healthy human pancreas. In contrast to the human samples with a diseased pancreas or to the normal rat pancreas, all six tested healthy human pancreas tissues were lacking bombesin receptors. It should, however, be noted that (a) the samples containing healthy human pancreas were from donor organs obtained under different conditions than the surgically resected tumor and pancreatitis samples and (b) that the healthy human exocrine pancreas is an enzymatically very active organ that may cause important and rapid degradation of bombesin or of the bombesin receptor. We therefore cannot completely exclude a technical reason for the generation of these negative data, that should, for the time being, be considered with some caution.

\section{Discussion}

To our knowledge, this is the first study evaluating bombesin receptor subtypes in cancerous and chronically inflamed human pancreatic tissue using a morphological method, ie, such as receptor autoradiography. Four receptor subtypes of the bombesin-like peptide family are presently known: the neuromedin B receptor with high affinity for neuromedin $B$, the GRP receptor with high affinity for GRP but lower affinity for neuromedin $\mathrm{B}$, and the bombesin receptor subtypes 3 and 4 with yet unidentified endogenous ligands (Fathi et al, 1993; Nagalla et al, 1995; Spindel et al, 1990; Von Schrenck et al, 1989). To identify in the present study the various bombesin receptor subtypes involved, we have used two approaches: We used the well established GRP receptor-preferring ligand ${ }^{125} \mid$ $\left[\mathrm{Tyr}^{4}\right]$-bombesin; this ligand could clearly detect GRP receptors in the diseased exocrine parenchyma and peritumoral vessels, characterized by the higher affinity displacement by GRP, bombesin, and GRP receptor antagonists than by neuromedin B. Also, we used 
Table 3. Bombesin-Receptor Expression in 29 Patients with Pancreatic Ductal Adenocarcinoma

\begin{tabular}{|c|c|c|c|c|}
\hline \multirow[b]{2}{*}{ No. } & \multirow{2}{*}{$\begin{array}{c}\begin{array}{c}\text { Pancreatic } \\
\text { ductal } \\
\text { adenocar- } \\
\text { cinoma }\end{array} \\
\text { Patient code }\end{array}$} & \multicolumn{3}{|c|}{$\begin{array}{l}\text { Bombesin-Receptor expression } \\
\text { (GRP-R subtype) }\end{array}$} \\
\hline & & $\begin{array}{l}\text { Cancer } \\
\text { cells }\end{array}$ & $\begin{array}{l}\text { Surrounding } \\
\text { parenchyma }\end{array}$ & $\begin{array}{l}\text { Surrounding } \\
\text { veins }\end{array}$ \\
\hline 1 & BP 541 & - & neg & + \\
\hline 2 & PEL & - & focal + & + \\
\hline 3 & STE & - & - & - \\
\hline 4 & CUM & - & neg & - \\
\hline 5 & TSC & - & neg & + \\
\hline 6 & BAN * $^{*}$ & - & - & + \\
\hline 7 & BP 32 & - & - & + \\
\hline 8 & BP 425 & - & neg & + \\
\hline 9 & BP 404 & - & neg & + \\
\hline 10 & BP 463 & - & neg & + \\
\hline 11 & BP 447 & - & focal + & + \\
\hline 12 & BP 12 & - & neg & + \\
\hline 13 & BP 559 & - & neg & + \\
\hline 14 & BP 569 & - & neg & - \\
\hline 15 & BP 112 & - & neg & - \\
\hline 16 & BP 592 & - & neg & NA \\
\hline 17 & HOF & - & neg & $N A$ \\
\hline 18 & MAR & - & neg & NA \\
\hline 19 & BP 206 & - & neg & + \\
\hline 20 & BP 267 & - & neg & - \\
\hline 21 & GAS & - & neg & + \\
\hline 22 & IMB & - & focal + & + \\
\hline 23 & BP 208 & - & neg & - \\
\hline 24 & BP 550 & - & neg & + \\
\hline 25 & BP 1280 & - & - & + \\
\hline 26 & BP 1318 & - & neg & - \\
\hline 27 & BP 1320 & - & neg & + \\
\hline 28 & GUS & - & focal + & + \\
\hline 29 & BP 1334 & - & neg & + \\
\hline $\begin{array}{l}+\mathrm{b} \\
-\mathrm{n} \\
\text { neg, } \\
\mathrm{NA},\end{array}$ & $\begin{array}{l}\text { esin receptors } \\
\text { mbesin recept } \\
\text { parenchyma in } \\
\text { assessable. }\end{array}$ & $\begin{array}{l}\text { ent, cha } \\
\text { sections }\end{array}$ & terized as GRP- & ubtype. \\
\hline
\end{tabular}

the newly developed universal ligand ${ }^{125} \mathrm{I}-\left[\mathrm{D}-\mathrm{Tyr}{ }^{6}\right.$, $\beta$-Ala ${ }^{11}, \mathrm{Phe}^{13}, \mathrm{Nle}^{14}$-bombesin(6-14) shown to label all four bombesin receptors (Pradhan et al, 1998). With this ligand we could also detect the GRP receptorexpressing exocrine parenchyma and peritumoral vessels characterized by high affinity displacement by GRP, bombesin, and GRP receptor antagonists but not neuromedin B. In addition, we could identify unequivocally in the residual pancreatic islets a subtype of bombesin receptors previously undetected with ${ }^{125} \mathrm{I}-\left[\mathrm{Tyr}^{4}\right]$-bombesin, which belongs to the BB3 subtype, characterized by high affinity displacement by [D-Tyr $\left.{ }^{6}, \beta-\mathrm{Ala}^{11}, \mathrm{Phe}^{13}, \mathrm{Nle}^{14}\right]$-bombesin(6-14) but not by GRP, bombesin, or neuromedin B (Pradhan et al, 1998).

A primary finding of the study is the detection of GRP receptors in the exocrine pancreatic parenchyma

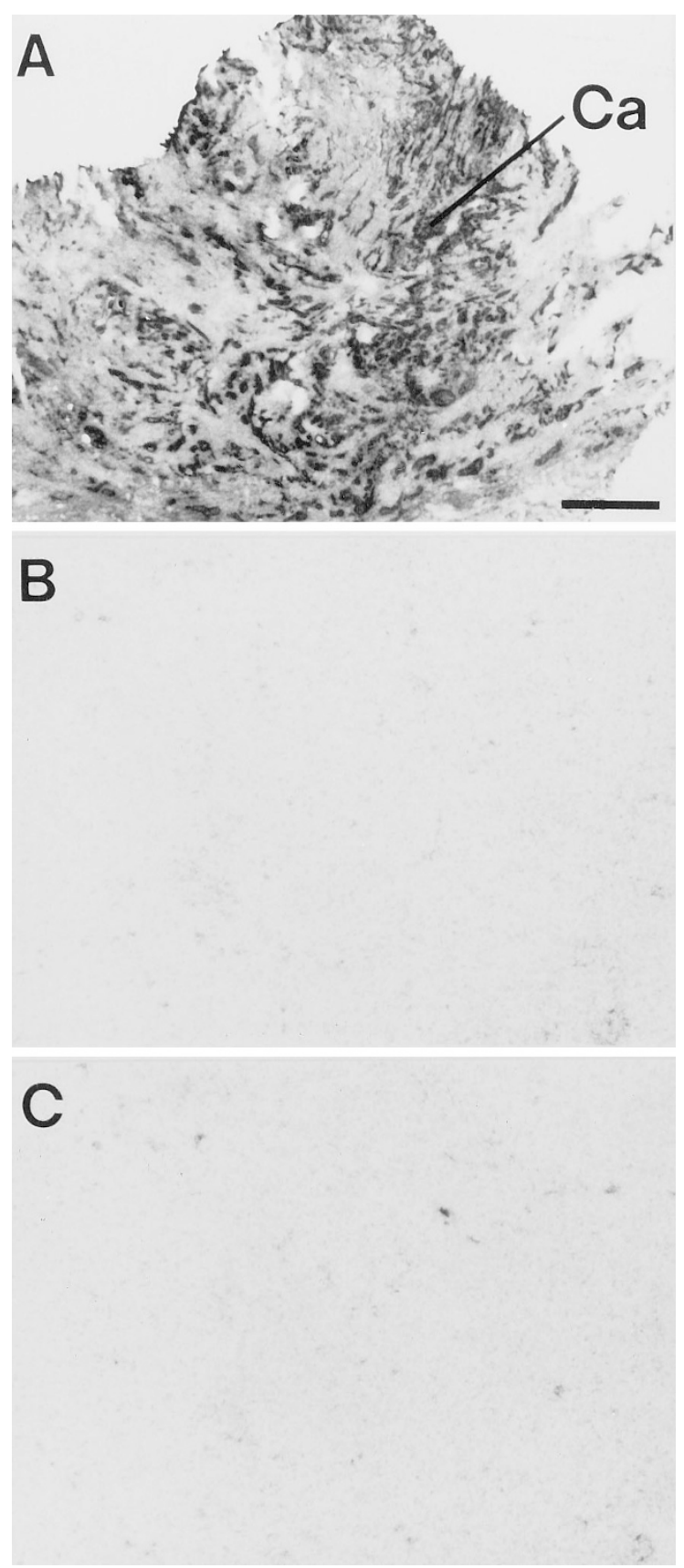

Figure 5.

Absence of GRP receptors in pancreatic carcinomatous tissue. A, H\&E stained section shows an example of ductal pancreatic adenocarcinoma (Ca). Bar $=1 \mathrm{~mm}$. B, Autoradiogram showing no binding of ${ }^{125} \mathrm{I}$-[Tyr $\left.{ }^{4}\right]$-bombesin to the carcinoma. $C$, Autoradiogram showing nonspecific binding of ${ }^{125}$ - $\left[\mathrm{Tyr}^{4}\right]$-bombesin.

of most patients with chronic pancreatitis. The density of GRP receptors was variable in the parenchyma and could not be correlated with the degree of fibrosis or inflammation. The presence of GRP receptors in chronic pancreatitis may be functionally meaningful in two aspects: First, their presence is meaningful in relation to the role of bombesin and related peptides as potent mitogens for normal pancreas (Upp et al, 1988) where they stimulate pancreatic growth in suckling and adult animals (Lehy and Puccio, 1988). During 

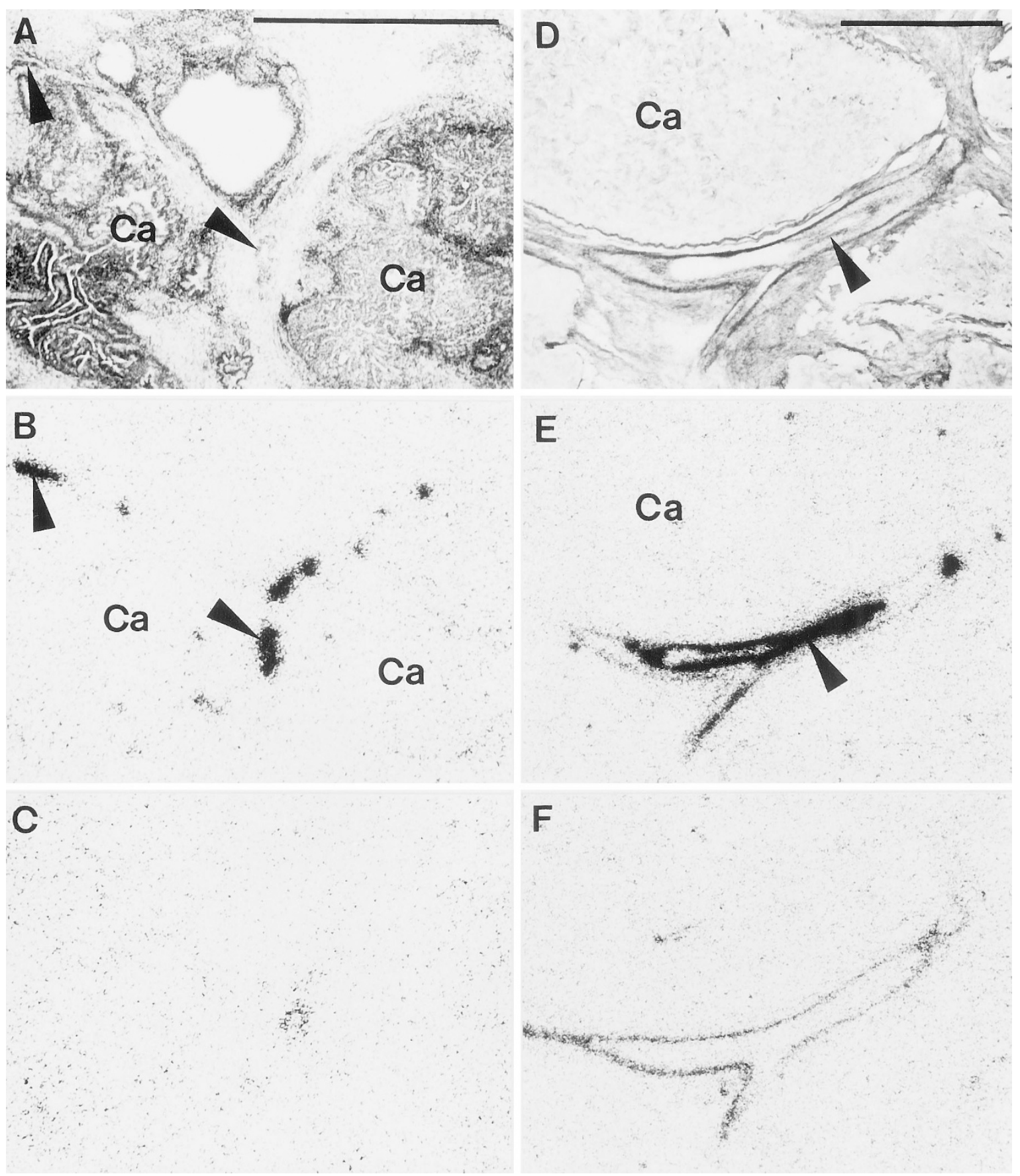

\section{Figure 6.}

Peritumoral expression of GRP receptors in blood vessels surrounding pancreatic adenocarcinoma. $A$, H\&E stained section shows an example of ductal pancreatic adenocarcinoma (Ca) with surrounding veins (arrowheads). Bar $=1 \mathrm{~mm}$. B. Autoradiogram showing binding of ${ }^{125}$ - $\left[\right.$ Tyr $\left.\mathrm{r}^{4}\right]$-bombesin to the peritumoral veins (arrowheads), but not to the tumor (Ca). C, Autoradiogram showing nonspecific binding of ${ }^{125}$-[Tyr $\left.{ }^{4}\right]$-bombesin. $D$, H\&E stained section shows an example of mucinous pancreatic adenocarcinoma (Ca) with a large surrounding vessel (arrowhead). Bar $=1 \mathrm{~mm}$. E. Autoradiogram showing strong binding of ${ }^{125} \mathrm{I}-\left[\mathrm{Tyr}^{4}\right]$-bombesin to the smooth muscles of the peritumoral veins (arrowhead) but no binding to the adenocarcinoma tissue. $F$, Autoradiogram showing residual nonspecific binding of ${ }^{125}$ - $\left[\mathrm{Tyr}^{4}\right]$-bombesin in the most external layer of the vessel.

chronic pancreatitis, the pancreas may try, through these GRP receptors, to make optimal use of the trophic function of GRP to counterbalance the reduction of pancreatic parenchyma occurring in the course of chronic pancreatitis, presumably through regeneration of the lost parenchyma. The particularly prominent GRP receptor expression at the border of the parenchymatous tissue, ie, in close contact with the fibrotically altered lesions, may support such a hypothesis and indicates the likely site of such a counter-regulation. Second, their presence is functionally meaningful in relation to the changes of the intrinsic and extrinsic innervation found in the chronically inflamed pancreas. Indeed, Bockman et al (1988) found ultra-structurally damaged nerves, an increase of the mean diameter of nerves and a decrease of the 
mean area of tissue served per nerve in chronic pancreatitis versus normal pancreas. Those nerves showed an increased expression of several neuropeptides (Buechler et al, 1992). Moreover, Shimosegawa et al (1993) discovered in chronic pancreatitis a frequent degeneration and fragmentation of nerve fibers displaying GRP-like immunoreactivity. The intrapancreatic nerve cell bodies, in contrast to those present in the healthy human pancreas, expressed a strong immunoreactivity for GRP, probably as a consequence of disturbed peptide transport, leading to an accumulation of GRP in the perikarya (Shimosegawa et al, 1993). It is conceivable, therefore, that the GRP receptors in the exocrine parenchyma of chronic pancreatitis will mediate abnormal neuronal information to the remaining exocrine glands, due to an altered GRP-mediated innervation. This abnormal neurotransmission may be one cause for pancreatic pain.

A second important finding of this study relates to ductal pancreatic carcinomas. No bombesin receptors could be found in the tumor tissue of our specimens; however, the GRP receptor subtype of bombesin receptor was detected in peritumoral small veins. The peritumoral vascular receptors in the samples containing ductal pancreatic cancer were identified in the smooth muscles of the veins. As already observed previously for peritumoral vessels expressing somatostatin receptors (Denzler and Reubi, 1999), not all peritumoral vessels were GRP receptor-positive. The reason for such a focal GRP receptor expression is unknown. Because GRP is known to induce smooth muscle contraction, the presence of GRP receptors in small vessels might affect the regulation of blood flow through vasoconstrictory actions and ultimately influence tumor development. Several mechanisms inducing the expression of GRP receptors in peritumoral vessels may be envisaged. Humoral factors secreted by the tumor (Folkman, 1995) may be instrumental for this enhanced expression. Such putative factors, released into tumoral blood vessels, may reach the peritumoral veins and influence the local vascular neuropeptide receptor expression. Another explanation could relate to the peripheral nervous system and its potential alteration when it innervates the tumoral and the peritumoral region (Mattsson et al, 1979). A neurogenic reaction has indeed been postulated to occur as a general biological response to various types of damage (Levine et al, 1986), including that caused by neoplasms; it may involve the peripheral peptidergic nervous system and its peptide receptors, including GRP, because it has been shown that GRPcontaining nerves occasionally reach the vasculature (De Giorgio et al, 1993).

The third important finding of this study is the identification, for the first time, of bombesin receptors of the BB3 subtype in human pancreatic islets. Because very little is known presently about the BB3 receptors (Fathi et al, 1993; Pradhan et al, 1998), the observation of a high density of this receptor in pancreatic islets, and moreover in the human species, may considerably increase the interest for this BB3 receptor subtype. It provides a possibility to further investigate its characteristics in a well defined human organ. This may open new avenues regarding the biology of this endocrine organ, and, as consequence, for future development and clinical applications of BB3-selective drugs.

A potential clinical application of the present findings may be the therapeutic and diagnostic use of GRP analogues. For pancreatic cancer, the modulation of hemodynamic parameters with GRP analogues in the immediate tumor surroundings might be a potential strategy to influence tumor growth through a putative lack of nutrients and oxygen. In chronic pancreatitis, it would be of diagnostic value to visualize chronic inflammatory pancreatic processes and to be able to differentiate them from neoplastic changes by means of GRP receptor scintigraphy in vivo (Behr et al, 1999; Krenning et al, 1995). It may be worth evaluating the use of GRP receptor antagonists (Jensen and Coy, 1991) for pain treatment in this disease to determine whether the parenchymatous GRP receptors may be responsible in part for the massive pain symptoms encountered during chronic pancreatitis. Alternatively, one may think of relieving pain in chronic pancreatitis with the use of radiolabeled GRP by locally destroying the altered nerves and reducing pain. This principle of selective destruction of receptor expressing tissues with radiotherapy is presently applied for somatostatin receptor expressing neuroendocrine and brain tumors (Merlo et al, 1999; Otte et al, 1998). Although largely speculative, these suggestions for pain therapy of chronic pancreatitis may represent an alternative to surgery in cases of persistent pain necessitating pancreatectomy.

\section{Material and Methods}

\section{Patients}

Tissues were obtained from 23 patients with chronic pancreatitis and 29 patients with pancreatic ductal carcinomas at the Department of Visceral Surgery, University Hospital (Berne, Switzerland). The samples (one per patient; 1-2 cm in diameter) of pathologic pancreatic tissue were collected in the operating room and immediately frozen at $-80^{\circ} \mathrm{C}$. Most of these tissue samples were investigated for other peptide receptors in previous experiments (Reubi et al, 1998) and their diagnoses were all reviewed by a pathologist (Oertel et al, 1994). All tested cases are listed in Tables 1 to 3.

\section{Bombesin Receptor Autoradiography}

Twenty-micron thick cryostat sections of the tissue samples were processed for receptor autoradiography as described in detail previously for other peptide receptors (Reubi et al, 1990). The radioligand used was ${ }^{125} \mathrm{I}-\left[\mathrm{Tyr}^{4}\right]$ bombesin, known to preferentially label GRP receptors (Vigna et al, 1987). For autoradiography, tissue sections were mounted on precleaned microscope slides and stored at $-20^{\circ} \mathrm{C}$ for at least 3 days to improve adhesion of tissue to the slide. The sections were then processed as described previously (Markwalder and Reubi, 1999; 
Vigna et al, 1987). They were first preincubated in $10 \mathrm{~mm}$ $\mathrm{N}$-2-hydroxyethylpiperazine-N'-2-ethane sulfonic acid (HEPES), pH 7.4, for 5 minutes at room temperature. They were then incubated in $10 \mathrm{~mm}$ HEPES, $130 \mathrm{~mm}$ $\mathrm{NaCl}, 4.7 \mathrm{~mm} \mathrm{KCl}, 5 \mathrm{~mm} \mathrm{MgCl}_{2}$, $1 \mathrm{~mm}$ ethylenglycol-bis ( $\beta$-aminoethylether)-N-N'-tetraacetic acid, $0.1 \%$ bovine serum albumin, $100 \mu \mathrm{g} / \mathrm{ml}$ bacitracin ( $\mathrm{pH} 7.4$ ), and approximately 100 pm ${ }^{125} \mathrm{I}_{-T y r^{4}}$-bombesin (2000 Ci/ $\mathrm{mmol}$; Anawa, Wangen, Switzerland) in the presence or absence of $1 \mu \mathrm{m}$ bombesin for 1 hour at room temperature. Additional sections were incubated in the presence of increasing amounts of nonradioactive bombesin, gastrin-releasing-peptide, neuromedin $B$, the bombesin receptor antagonists [D-Phe $\left.{ }^{6}\right]$-bombesin(6-13) NHEt (Bachem, Bubendorf, Switzerland) and [D-Phe ${ }^{6}$, Leu $^{13}$ $\psi\left(\mathrm{CH}_{2} \mathrm{NH}\right) \quad$ Leu $^{14}$ ]-bombesin(6-14) (Novabiochem, Läufelfingen, Switzerland) or somatostatin (Bachem, Bubendorf, Switzerland) to generate competitive inhibition curves. After incubation, the sections were washed four times for 2 minutes each in $10 \mathrm{~mm}$ HEPES with $0.1 \%$ bovine serum albumin ( $\mathrm{pH} \mathrm{7.4)}$ at $4^{\circ} \mathrm{C}$. Finally, the slides were rinsed twice for 5 seconds each at $4^{\circ} \mathrm{C}$ in distilled water. The slides were then dried at $4^{\circ} \mathrm{C}$ under a stream of cold air. The slides were placed in apposition to ${ }^{3} \mathrm{H}$-Hyperfilms (Amersham, Aylesbury, United Kingdom) and exposed for 7 days to x-ray cassettes.

To be able to distinguish the different bombesin receptor subtypes, we have also tested all samples with the newly developed radioligand ${ }^{125} \mathrm{I}-\left[\mathrm{D}-\mathrm{Tyr}^{6}\right.$, $\beta$-Ala ${ }^{11}, \mathrm{Phe}^{13}, \mathrm{Nle}^{14}$ ]-bombesin(6-14), which has been reported to be an outstanding ligand identifying all four bombesin receptor subtypes (Pradhan et al, 1998). Because each of these subtypes is characterized by a specific rank order of potencies of GRP, bombesin, NMB, and [D-Tyr ${ }^{6}, \beta-\mathrm{Ala}^{11}, \mathrm{Phe}^{13}, \mathrm{Nle}^{14}$ ]bombesin(6-14), the use of these four peptides as unlabeled competitors in displacement experiments allows us to identify each various receptor subtype expressed in the tissues (Pradhan et al, 1998). In preliminary experiments using ${ }^{125} \mathrm{I}-\left[\mathrm{Tyr}^{4}\right]$-bombesin, the affinity of the two unlabeled universal ligands $\left[\mathrm{Phe}^{6}, \beta-\mathrm{Ala}^{11}, \mathrm{Phe}^{13}, \mathrm{Nle}^{14}\right]$-bombesin(6-14) and $\left[\mathrm{Tyr}^{6}, \beta-\mathrm{Ala}^{11}, \mathrm{Phe}^{13}, \mathrm{Nle}^{14}\right]$-bombesin(6-14) (Pradhan et al, 1998) was assessed in human GRP receptorexpressing prostate cancers and compared with GRP receptor-expressing rat pancreas (Pradhan et al, 1998). Whereas $I C_{50}$ values (mean \pm SEM; $n>3$ ) for bombesin, [D-Tyr $\left.{ }^{6}, \beta-\mathrm{Ala}^{11}, \mathrm{Phe}^{13}, \mathrm{Nle}^{14}\right]$-bombesin(6-14), and [D-Phe $\left.{ }^{6}, \beta-\mathrm{Ala}^{11}, \mathrm{Phe}^{13}, \mathrm{Nle}^{14}\right]$-bombesin(6-14) were $3.1 \pm 0.6 \mathrm{~nm}, 0.07 \pm 0.01 \mathrm{~nm}$, and $0.07 \pm 0.01 \mathrm{~nm}$ in rat pancreas, they were $4.5 \pm 0.2$ $\mathrm{nm}, 2.0 \pm 0.6 \mathrm{~nm}$, and $2.2 \pm 0.6 \mathrm{~nm}$ in prostate cancer. The approximately 30 times difference in affinity of the two synthetic analogues between human and rat GRP receptor-expressing tissues points toward a strong species variability in the binding characteristics of these two synthetic peptides. Nevertheless, the $\mathrm{IC}_{50}$ in the nanomolar range of [D-Tyr $\left.{ }^{6}, \beta-\mathrm{Ala}^{11}, \mathrm{Phe}^{13}, \mathrm{Nle}^{14}\right]$ bombesin(6-14) in human tissue strongly indicates that this compound remains an adequate candidate as radioligand in this type of receptor autoradiographic studies. The compound was therefore iodinated and purified by HPLC by Anawa (Wangen, Switzerland; $2000 \mathrm{Ci} / \mathrm{mmol}$ ), as reported previously (Gugger and Reubi, 1999). For autoradiographic studies with this ligand, conditions identical with those reported above for ${ }^{125} \mathrm{I}-\left[\mathrm{Tyr}^{4}\right]$-bombesin were used, except that a concentration of $20 \mathrm{pm}$ of this radioligand was chosen in the incubation solution.

The autoradiograms were quantified using a computer assisted image processing system, as described previously (Gugger and Reubi, 1999; Markwalder and Reubi, 1999; Reubi et al, 1990). Radiolabeled tissue sections were exposed to ${ }^{3} \mathrm{H}$-Hyperfilms together with standards (Autoradiographic [ $\left.{ }^{125} \mathrm{I}\right] \mathrm{microscales,} \mathrm{Amer-}$ sham) that contained known amounts of isotope, cross-calibrated to tissue-equivalent ligand concentration. The image analyzer was calibrated to the standards; it performed interpolation to read values that lay between those of the film standard. A tissue was defined as receptor-positive when the optical density measured in the total binding section was at least twice that of the nonspecific binding section (in the presence of $10^{-6} \mathrm{M}$ bombesin). An average of at least three receptor autoradiography experiments was performed with each tissue sample for evaluation of the receptor localization at the microscopic level.

\section{References}

Behr TM, Jenner N, Behe M, Angerstein C, Gratz S, Raue F, and Becker W (1999). Radiolabeled peptides for targeting cholecystokinin-B/gastrin receptor-expressing tumors. J Nucl Med 40:1029-1044.

Bockman DE, Buchler M, Malfertheiner P, and Beger HG (1988). Analysis of nerves in chronic pancreatitis. Gastroenterology 94:1459-1469.

Buechler M, Weihe E, Friess H, Malfertheiner P, Bockman E, Muller S, Nohr D, and Beger HG (1992). Changes in peptidergic innervation in chronic pancreatitis. Pancreas 7:183192.

Chung DH, Evers BM, Beauchamp RD, Upp JR Jr, Rajaraman S, Townsend CM Jr, and Thompson JC (1992). Bombesin stimulates growth of human gastrinoma. Surgery 112: 1059-1065.

Coy DH, Taylor JE, Jiang N-Y, Kim SH, Wang L-H, Huang S, Moreau J-P, Gardner JD, and Jensen RT (1989). Short-chain pseudopeptide bombesin receptor antagonists with enhanced binding affinities for pancreatic acinar and Swiss 3T3 cells display strong antimitotic activity. J Biol Chem 264: 1491-1497.

Cuttitta F, Carney DN, Mulshine J, Moody TW, Fedorko J, Fischler A, and Minna JD (1985). Bombesin-like peptides can function as autocrine growth factors in human small-cell lung cancer. Nature 316:823-826.

De Giorgio R, Sternini C, Widdison AL, Alvarez C, Brecha NC, Reber HA, and Go VL (1993). Differential effects of experimentally induced chronic pancreatitis on neuropeptide immunoreactivities in the feline pancreas. Pancreas 8:700-710.

Denzler B and Reubi JC (1999). Expression of Somatostatin receptors in peritumoral veins of human tumors. Cancer 85:188-198. 
Deschodt-Lanckman M, Robberecht P, De Neef P, Lammens $\mathrm{M}$, and Christophe J (1976). In vitro action of bombesin and bombesin-like peptides on amylase secretion, calcium efflux, and adenylate cyclase activity in the rat pancreas. $\mathrm{J}$ Clin Invest 58:891-898.

Dockray GJ, Vaillant C, and Walsh JH (1979). The neuronal origin of bombesin-like immunoreactivity in the rat gastrointestinal tract. Neuroscience 4:1561-1568.

Erspamer V (1988). Discovery, isolation, and characterization of bombesin-like peptides. Ann N Y Acad Sci 547:3-9.

Fathi Z, Corjay MH, Shapira H, Wada E, Benya R, Jensen R, Viallet J, Sausville EA, and Battey JF (1993). BRS-3: Novel bombesin receptor subtype selectively expressed in testis and lung carcinoma cells. J Biol Chem 268:5979-5984.

Folkman J (1995). Angiogenesis in cancer, vascular, rheumatoid and other disease. Nat Med 1:27-31.

Frucht H, Gazdar AF, Park JA, Oie H, and Jensen RT (1992). Characterization of functional receptors for gastrointestinal hormones on human colon cancer cells. Cancer Res 52: 1114-1122.

Gugger M and Reubi J (1999). GRP receptors in nonneoplastic and neoplastic human breast. Am J Pathol 155: 2067-2076.

Hajri A, Koenig M, Balboni G, and Damge C (1996). Expression and characterization of gastrin-releasing peptide receptor in normal and cancerous pancreas. Pancreas 12:25-35.

Hennig IM, Laissue JA, Horisberger U, and Reubi JC (1995). Substance-P receptors in human primary neoplasms: Tumoral and vascular localization. Int J Cancer 61:786-792.

Huang SC, Yu D-H, Wank SA, Gardner JD, and Jensen RT (1990). Characterization of the bombesin receptor or mouse pancreatic acini by chemical cross-linking. Peptides 11: 1143-1150.

Jensen RT and Coy DH (1991). Progress in the development of potent bombesin receptor antagonists. Trends Pharmacol Sci 12:13-19.

Jensen RT, Moody T, Pert C, Rivier JE, and Gardner JD (1978). Interaction of bombesin and litorin with specific membrane receptors on pancreatic acinar cells. Proc Natl Acad Sci 75:6139-6143.

Krenning EP, Kwekkeboom DJ, Pauwels S, Kvols LK, and Reubi JC (1995). Somatostatin receptor scintigraphy. Nucl Med Annual 1995:1-50.

Kroog GS, Jensen RT, and Battey JF (1995). Mammalian bombesin receptors. Med Res Rev 15:389-417.

Lehy $T$ and Puccio F (1988). Influence of bombesin on gastrointestinal and pancreatic cell growth in adult and suckling animals. Ann N Y Acad Sci 547:255-267.

Levine JD, Dardick SJ, Roizen MF, Helms C, and Basbaum AI (1986). Contribution of sensory afferents and sympathetic efferents to joint injury in experimental arthritis. J Neurosci 6:3423-3429.

Mantyh P, Catton M, Maggio J, and Vigna S (1991). Alterations in receptors for sensory neuropeptides in human inflammatory bowel disease. Adv Exp Med Biol 298:253-283.

Markwalder R and Reubi JC (1999). Gastrin-releasing peptide receptors in the human prostate: relation to neoplastic transformation. Cancer Res 59:1152-1159.
Mattsson J, Appelren L, Hamberger B, and Peterson H (1979). Tumor vessel innervation and influence of vasoactive drugs on tumor blood flow. In: Peterson $\mathrm{H}$ (ed.) Tumor blood circulation. Boca Raton, FL: CRC Press Inc, 129-135.

Merlo A, Hausmann O, Wasner M, Steiner P, Otte A, Jermann E, Freitag P, Reubi JC, Müller-Brand J, Gratzl O, and Mäcke HR (1999). Locoregional regulatory peptide receptor targeting with the diffusible somatostatin analogue ${ }^{90} \mathrm{Y}$-labeled DOTA ${ }^{0}$-D-Phe ${ }^{1}-$ Tyr $^{3}$-octreotide (DOTATOC): A pilot study in human gliomas. Clin Cancer Res 5:1025-1033.

Moghimzadeh E, Ekman R, Hakanson R, Yanaihara N, and Sundler F (1983). Neuronal gastrin-releasing peptide in the mammalian gut and pancreas. Neuroscience 10:553-563.

Nagalla SR, Barry BJ, Creswick KC, Eden P, Taylor JT, and Spindel ER (1995). Cloning of a receptor for amphibian [Phe13]bombesin distinct from the receptor for gastrinreleasing peptide: Identification of a fourth bombesin receptor subtype (BB4). Proc Natl Acad Sci USA 92:6205-6209.

Oertel JE, Oertel YC, and Heffess CS (1994). Pancreas. In: Sternberg SS, editor: Diagnostic surgical pathology. Philadelphia, New York: Lippincott-Raven, 1419-1457.

Otte A, Mueller-Brand J, Dellas S, Nitzsche EU, Herrmann R, and Maecke HR (1998). Yttrium-90-labelled somatostatinanalogue for cancer treatment [letter]. Lancet 351:417-418.

Pradhan TK, Katsuno T, Taylor JE, Kim SH, Ryan RR, Mantey SA, Donohue PJ, Weber HC, Sainz E, Battey JF, Coy DH, and Jensen RT (1998). Identification of a unique ligand which has high affinity for all four bombesin receptor subtypes. Eur J Pharmacol 343:275-287.

Reubi JC (1995a). In vitro identification of vasoactive intestinal peptide receptors in human tumors: Implications for tumor imaging. J Nucl Med 36:1846-1853.

Reubi JC (1995b). Neuropeptide receptors in health and disease: The molecular basis for in vivo imaging. J Nucl Med $36: 1825-1835$.

Reubi JC, Kvols LK, Waser B, Nagorney DM, Heitz PU, Charboneau JW, Reading CC, and Moertel C (1990). Detection of somatostatin receptors in surgical and percutaneous needle biopsy samples of carcinoids and islet cell carcinomas. Cancer Res 50:5969-5977.

Reubi JC, Waser B, Friess H, Büchler MW, and Laissue JA (1998). Neurotensin receptors: A new marker for human ductal pancreatic adenocarcinoma. Gut 42:546-550.

Shimosegawa T, Asakura T, Kashimura J, Yoshida K, Meguro T, Koizumi M, Mochizuki T, Yanaihara N, and Toyota T (1993). Neurons containing gastrin releasing peptide-like immunoreactivity in the human pancreas. Pancreas 8:403-412.

Spindel ER, Giladi E, Brehm P, Goodman RH, and Segerson TP (1990). Cloning and functional characterization of a complementary DNA encoding the murine fibroblast bombesin/ gastrin-releasing peptide receptor. Mol Endocrinol 4:19561963.

Tang C, Biemond I, Offerhaus GJ, Verspaget W, and Lamers CB (1997). Expression of receptors for gut peptides in human pancreatic adenocarcinoma and tumour-free pancreas. $\mathrm{Br} \mathrm{J}$ Cancer 75:1467-1473.

Upp JR, Jr., Poston GJ, MacLellan DG, Townsend CM, Jr., Barranco SC, and Thompson JC (1988). Mechanisms of the trophic actions of bombesin on the pancreas. Pancreas 3:193-198. 
Vigna SR, Mantyh CR, Giraud AS, Soll AH, Walsh JH, and Mantyh PW (1987). Localization of specific binding sites for bombesin in the canine gastrointestinal tract. Gastroenterology 93:1287-1295.

Virgolini I, Raderer M, Kurtaran A, Angelberger P, Banyai S, Yang Q, Li S, Banyai M, Pidlich J, Niederle B, Scheithauer W, and Valent $P$ (1994). Vasoactive intestinal peptide-receptor imaging for the localization of intestinal adenocarcinomas and endocrine tumors. N Engl J Med 331:1116-1121.

Von Schrenck T, Heinz-Erian P, Moran T, Mantey SA, Gardner JD, and Jensen RT (1989). Neuromedin B receptor in esophagus: Evidence for subtypes of bombesin receptors. Am J Physiol 256:G747-G758.
Walsh DA, Mapp PI, Wharton J, Rutherford RA, Kidd BL, Revell PA, Blake DR, and Polak JM (1992). Localisation and characterisation of substance $P$ binding to human synovial tissue in rheumatoid arthritis. Ann Rheum Dis 51:313-317.

Wang QJ, Knezetic JA, Schally AV, Pour PM, and Adrian TE (1996). Bombesin may stimulate proliferation of human pancreatic cancer cells through an autocrine pathway. Int $\mathrm{J}$ Cancer 68:528-534.

Yano T, Pinski J, Groot K, and Schally AV (1992). Stimulation by bombesin and inhibition by bombesin/gastrin-releasing peptide antagonist RC-3095 of growth of human breast cancer cell lines. Cancer Res 52:4545-4547. 